\title{
Empathic Love Therapy untuk Menurunkan Pikiran dan Perilaku Self Injury
}

\author{
Tri Permatasari ${ }^{1}$ E Budi Andayani² \\ Fakultas Psikologi Universitas Gadjah Mada
}

\begin{abstract}
Self injury is the act of deliberately inflicting harm on ones own body without suicidal intent. Prevalence of people with self injury is constantly increased each year especially in teenager and young adults. Empathic love therapy (ELT) is a method of love in psychosynthesis to reconcile every aspect in self, to change the destructive self pattern, and to find one's true Self that in line with God's will. The purpose of this study is to test the effectiveness of ELT in reducing self injury. There are 3 participants aged 20-30 years old which shows symptoms of self injury in the past year. This study use a single case design study. The measuring instrument are Daily Self Assessment (Diary) and Assessment of Empathic Love Therapy Sheets. Data analysis was performed by visual inspection and qualitative analysis. The finding of this study shows that ELT perform effectively in reducing self injury.
\end{abstract}

Keywords: empathic love therapy; psychosynthesis; self injury; transpersonal psychology

Abstrak. Self injury merupakan perilaku menyakiti diri sendiri untuk mendapatkan rasa sakit dengan sengaja sebagai ungkapan ekspresi perasaan yang tidak menyenangkan, tanpa maksud bunuh diri. Prevalensi individu dengan self injury semakin meningkat dari tahun ke tahun, sementara belum ditemukan cara yang tepat dalam menanganinya. Empathic Love Therapy (ELT) merupakan metode cinta dalam psikosintesis untuk mendamaikan seluruh aspek dalam diri, mengubah pola diri yang bersifat membatasi ataupun merusak diri, dan menemukan diri sejati yang sejalan dengan kehendak Tuhan. Tujuan penelitian adalah menguji efektivitas ELT dalam menurunkan pikiran dan perilaku self injury. Partisipan penelitian berjumlah tiga orang, usia 20-30 tahun, memiliki pikiran dan perilaku self injury satu tahun terakhir. Penelitian ini menggunakan single case design. Alat ukur yang digunakan berupa Penilaian Diri Harian (Diari) dan lembar Assessment of Emphatic Love Therapy. Analisis data dilakukan dengan inspeksi visual dan analisis kualitatif. Hasil Penelitian menunjukkan ELT efektif untuk menurunkan pikiran dan perilaku self injury.

Kata kunci : empathic love therapy; psikologi transpersonal; psikosintesis; self injury

Self injury atau menyakiti diri sendiri dilakukan untuk mendapatkan rasa sakit atau luka dengan sengaja sebagai ungkapan ekspresi perasaan yang tidak

${ }^{1}$ Korespondensi mengenai isi artikel ini dapat dilakukan melalui : tri.permata.sari@mail.ugm.ac.id

${ }^{2}$ Atau melalui anikoentjoro@ugm.ac.id menyenangkan. Luka yang ditimbulkan sifatnya minor sampai moderat, sehingga perilaku ini bukan merupakan usaha untuk bunuh diri.

Self injury dilakukan hampir di setiap rentang usia, mulai dari anak-anak sampai dewasa. Pada anak-anak dan remaja diperoleh tingkat prevalensi antara 
1,5-5,6\% (Albores-Gallo, Méndez-Santos, Xóchitl-Garcia Luna, Delgadillo-González, Chávez-Flores, \& Martínez, 2014), pada remaja yaitu 49,2\% (Manca, Presaghi, \& Cerutti; 2014), pada dewasa awal yaitu 37\% (Gratz, Dixon-Gordon, Chapman, \& Tull., 2015). Paling banyak melakukan self injury ada di usia remaja dan dewasa awal, dengan tingkat prevalensi 36,9-50\% (Glenn \& Klonsky, 2013). Usia kemunculan self injury diketahui berada di usia awal remaja, (Glenn \& Klonsky, 2009; Klonsky 2011) menyebut 13 atau 14 tahun merupakan onset (pertama kali) seseorang melakukan self injury.

Peneliti melakukan wawancara preeleminary terhadap subjek $C$, dewasa awal yang memiliki pikiran ataupun perilaku self injury. Kebiasaan subjek C melakukan self injury terkadang didahului oleh pikiran-pikiran yang berulang tentang self injury. Pikiran itu terus meningkat sampai akhirnya subjek $C$ melakukannya dalam perilaku. Namun terkadang juga subjek $\mathrm{C}$ langsung melakukan perilaku self injury tanpa didahului pikiran tentang self injury.

Metode self injury bermacam-macam, (Baetens. et al, (2015); (Lloyd-Richardson, Perrine, Dierker, \& Kelley, 2007) menyebutkan bahwa metode yang paling banyak dipilih orang ketika melakukan memukul, meninju, menjambak rambut, ataupun mengiris pergelangan tangan.

Nock $(2004,2005,2010)$ membagi self injury menjadi dua fungsi yaitu fungsi intrapersonal dan fungsi interpersonal. Fungsi yang paling banyak dilakukan orang adalah fungsi intrapersonal, yaitu regulasi diri, self-punishment, anti-disosiasi (Klonsky, 2007, 2009, 2011; Klonsky \& Glenn, 2009). Subjek C berpikir dan melakukan self injury untuk meredakan kemarahan dan kebencian yang dirasakannya terhadap diri sendiri maupun orang lain. Selain itu, C merasa pantas mendapatkan hukuman atas kebodohan dan perilaku tidak tepat yang ia lakukan sehingga berujung pada kegagalan.

Pengalaman-pengalaman tidak menyenangkan dengan orang terdekat, misalnya keluarga, khususnya interaksi yang buruk dengan ibu sangat berhubungan dengan kemunculan self injury (Pierro, Sarno, Perego, Gallucci, \& Madeddu, 2012). Beatens et al., 2015; Glassman, Weierich, Hooley, Deliberto, \& Nock, 2007; Nock, 2010, menyebutkan bahwa pengabaian, penganiaan, penolakan, kritikan berlebih, kurangnya dukungan emosional, menyebabkan seseorang mengembangkan gaya berpikir kritis "berlebihan" terhadap diri. Gaya berpikir kritis berlebihan kepada diri dikatakan memiliki kontribusi yang sangat besar dalam self injury. Selain menimbulkan kemarahan dan kebencian yang mendalam terhadap diri, kritik berlebihan juga menyebabkan individu selalu meragukan kemampuannya, tidak ada penghargaan atas diri, dan sangat mudah merasakan perasaan bersalah atas apa saja yang dilakukannya. Individu yang melakukan self injury juga diketahui sering mengalami ketergugahan akan emosi dan pikiran-pikiran negatif, mereka lebih banyak merasakan hal-hal negatif di sekelilingnya. Ditambah dengan kurangnya keterampilan emosi, meliputi; toleransi rendah terhadap kejadian buruk yang menimpa, sulit mengekspresikan apa yang dirasakan, dan memiliki kemampuan buruk dalam penyelesaian masalah (Yurkowski et al., 2015; Bentley, Nock, \& Barlow, 2014; Nock 2010).

Penelitian oleh (Glenn \& Klosky, 2009) menunjukkan sekali seseorang terlibat dalam self injury, besar kemungkinan ia akan mengulangi perilakunya tersebut, bahkan dengan intensitas yang semakin meningkat setiap waktunya. Oleh karena itu perlu 
penanganan tepat untuk mencegah resiko yang lebih besar, misalnya self injury yang mengarah pada rencana ataupun usaha bunuh diri. Sekalipun berbeda dengan kecenderungan ataupun usaha bunuh diri, namun beberapa penelitian menujukkan hubungan yang erat antara self injuryberulang dengan resiko bunuh diri, dan self injury yang memiliki tingkat keparahan-sedang-ke atas dengan resiko bunuh diri (Lloyd-Richardson, Dierker, \& Kelley, 2007; Guan, Fox, \& Prinstein, 2012; Mehlenkamp, Claes, Havertape \& Plener, 2012).

Salah satu penanganan yang dapat diambil adalah melakukan intervensi psikologis dengan pendekatan transpersonal. Pendekatan transpersonal dianggap sebagai pendekatan yang paling komprehensif. Assagioli (dalam Rueffler, 1995) menyebutkan dalam pendekatan transpersonal terdapat dua tujuan terapi, yaitu tujuan personal untuk memperkuat perkembangan kepribadian dengan melibatkan semua proses mental di dalamnya baik itu pikiran, perasaan dan perilaku untuk menuju selaras dan optimal. Sedangkan tujuan transpersonal lebih dalam lagi, yaitu menawarkan kemungkinan untuk mewujudkan diri yang sejati, menyangkut keterhubungan manusia dengan Sang Pencipta.

Salah satu intervensi psikologis dengan pendekatan psikologi transpersonal adalah metode Empathic Love Therapy (ELT). Metode ELT merupakan metode cinta dalam psikosintesis untuk mendamaikan seluruh aspek dalam diri, mengubah pola diri yang bersifat membatasi atau merusak diri, dan menemukan diri sejati yang utuh dan sejalan dengan kehendak Tuhan.

Segala tindakan yang merusak diri ataupun tindakan yang membatasi potensi diri terjadi karena $I$ (personal) dan Self (transpersonal) tidak utuh. I dan Self yang tidak utuh karena $I$ mengalami luka yang disebut primal wounding (Firman \& Gila, 2002). Primal Wounding muncul karena pengalaman-pengalaman tidak menyenangkan di masa lalu seperti penolakan, perpisahan, pengabaian ataupun hal-hal yang tidak empati lainnya yang dilakukan oleh significant others (orang tua, pengasuh) dan lingkungan (peers, masyarakat, sistem) baik disengaja maupun tidak disengaja.

Primal wounding membuat individu merasakan perasaan tidak menyenangkan seperti merasa kosong, terisolasi, kehilangan aku yang utuh, tidak bermakna, tidak berharga, selalu salah, merasa kewalahan dan terjebak, cemas dan putus asa (Firman \& Gila, 2002). Untuk membebaskan diri dari kondisi tidak menyenangkan tersebut, maka muncul pribadi bertahan atau I survival. I survival yang ingin membebaskan diri dari luka, ingin mengekspresikan kekacauan perasaan, dalam penelitian ini yaitu self injury.

Penelitian ELT sudah pernah dilakukan di Indonesia, beberapa diantaranya yaitu ELT diberikan kepada individu dengan permasalahan depresi (Saragih, 2014; Sagala, 2015; Widiasari, 2015), dan ELT diberikan kepada individu dengan permasalahan kecemasan (Tittarini, 2014; Yana, 2015). Beberapa penelitan pun menunjukkan hubungan yang erat antara depresi dan kecemasan dengan self injury (Klonsky, 2007, 2009; Laye-Gindhu \& Schoner-Reichl, 2005; Marshall, Weaver, \& Stattin, 2013).

Hasil penelitian, ELT terbukti efektif menurunkan depresi dan kecemasan. ELT menurunkan depresi dan kecemasan dengan meningkatkan keberhargaan dan penerimaan diri. Rasa berharga dan penerimaan terhadap segala elemen diri, baik yang menyakitkan maupun menyenangkan membawa individu- 
individu tersebut menemukan diri yang utuh dan tidak terbatas. Adapun rasa berharga oleh (Kool, Meijel, \& Bosman, 2009) disebut merupakan salah satu faktor yang membuat seseorang mampu menghentikan perilaku sel injury.

Penelitian ini bertujuan untuk menguji efektivitas Empathic Love Therapy untuk menurunkan pikiran dan perilaku self injury. Pertanyaan dalam penelitian ini adalah apakah ELT dapat menurunkan pikiran dan perilaku self injury. Hasil penelitian diharapkan memberikan manfaat bagi partisipan yaitu penurunan pikiran dan perilaku self injury dan memperkaya khasanah ilmu psikologi dalam penggunaan dan pengembangan psikologi psikosintesis di Indonesia.

\section{Metode}

\section{Partisipan penelitian}

Partisipan dalam penelitian ini berjumlah tiga orang dengan kriteria yaitu; berumur 20-30 tahun, bersedia mengikuti penelitian dengan telah menandatangani Informed Consent yang sesuai dengan etika penelitian, memenuhi kriteria Diagnostic and Statistical Manual of Mental Disorders (DSM-V) untuk self injury (non suicidial self injury) dari hasil wawancara awal.

\section{Instrumen}

Instrumen penelitian yang digunakan berupa lembar penilaian diri (diary), lembar observasi, dan lembar assesment of empathic love therapy. Diary berisi lembar penilaian diri untuk mengetahui kondisi harian berupa pikiran dan perilaku self injury yang dilakukan partisipan. Diari juga berisi gambaran peristiwa dan bagaimana perasaan dan pikiran partisipan terkait peristiwa yang dialaminya tersebut. Diari diisi setiap hari mulai dari amatan 1 sampai dengan amatan 2. Lembar observasi digunakan untuk memandu observer selama mengamati jalannya proses terapi. Aspek yang diamati, meliputi kesan umum, kondisi partisipan, dan gambaran spesifik dalam pelaksanaan terapi. Observer mengamati jalannya proses terapi melalui rekaman video. Lembar Assessment of Empathic Love Therapy bertujuan untuk mengetahui tingkat keberhasilan dan kebermanfaatan terapi. Instrumen ini terdiri dari General Overall Assessment (GOA) dan Specific Assessment and Reactions to Empathic Love Therapy (SAR). GOA terdiri atas dua pertanyaan terbuka tentang pengalaman saat mengikuti terapi dan sesi yang dirasa paling efektif, tiga aitem skala likert tentang penilaian setiap sesi, dan satu aitem rating tentang sejauh mana partisipan akan merekomendasikan ELT ke orang lain. SAR terdiri atas empat pertanyaan terbuka tentang kebermanfaatan terapi, perubahan yang terjadi setelah mengikuti ELT, sesi yang akan diulangi maupun sesi yang tidak ingin diulangi. Lembar Asesmen diberikan setelah intervensi sesi terakhir selesai dilaksanakan.

\section{Desain penelitian}

Penelitian ini menggunakan desain penelitian A-B-A single case design (Kazdin, 2011). Berbeda dengan desain yang menggunakan kelompok, desain yang menggunakan jumlah $\mathrm{N}$ yang sedikit lebih menekankan pada perubahan individual (Barlow \& Hersen, 1987).

Penelitian single case design menggunakan pengukuran dan manipulasi yang sistematis, pengukuran variabel dependen dilakukan pada setiap fase penelitian. Fase amatan 1 yaitu pengukuran kondisi stabil partisipan sebelum intervensi. Kondisi stabil yang dimaksud adalah sampai terlihat tren/kecenderungan kondisi partisipan. Fase intervensi yaitu pengukuran selama 
Tabel 1.

Data demografis partisipan

\begin{tabular}{llllllll}
\hline \multicolumn{1}{c}{ Nama } & JK & Usia & Anak ke- & \multicolumn{1}{c}{ Agama } & \multicolumn{1}{c}{ Pendidikan } & Alamat Asal & Status \\
\hline Kirana & P & 22 & 1 dari 3 & Islam & Mahasiswa S1 semester 5 & Pangandaran & Belum menikah \\
Satrio & L & 28 & 3 dari 3 & Islam & Mahasiswa S2 semester 7 & Bengkulu & Belum menikah \\
Laksmi & P & 20 & 1 dari 3 & Protestan & Mahasiswa S1 semester 5 & Gunung Kidul & Belum menikah \\
\hline
\end{tabular}

perlakuan (intervensi) diberikan.

Sedangkan fase amatan dua yaitu pengukuran kembali kondisi partisipan setelah tidak mendapatkan perlakukan.

\section{Variabel penelitian}

Variabel dependen dalam penelitian ini adalah self injury. Self injury yaitu pikiran dan perilaku menyakiti atau membahayakan diri sendiri dengan sengaja dan tanpa bermaksud untuk bunuh diri dengan tujuan meringankan permasalahan emosi. Variabel independen dalam penelitian ini yakni Empathic Love Therapy. Terapi ELT dilakukan secara individual selama tujuh kali pertemuan. Masing-masing pertemuan berlangsung sekitar 120-180 menit.

\section{Analisis data}

Pengukuran variabel dependen dilakukan dengan penilaian diri harian (diari). Pada penelitian ini dilakukan perbandingan diari partisipan antara fase amatan 1, fase intervensi, dan fase amatan 2. Analisis data dilakukan dengan inspeksi visual, yaitu menggunakan grafik untuk memperlihatkan perubahan yang terjadi antar fase. Adapun perubahan yang dimaksud adalah perubahan mean, stabilitas, level, dan tren (Kazdin, 2011). Selanjutnya analisis didukung dengan data deskriptif yang diperoleh dari observasi, wawancara, catatan selama terapi, dan cerita dari diari.

Data yang diperoleh dibuat grafik garis dengan menggunakan Microsoft Excel. Perubahan mean ditunjukkan dengan garis horizontal. Perubahan stabilitas digunakan standar deviasi. Kecenderungan arah atau garis tren ditunjukkan dengan regresi linear. Sementara untuk perubahan level dilihat dari perubahan fase terakhir suatu fase dengan hari pertama fase selanjutnya (Kazdin, 2011).

\section{Hasil}

\section{Partisipan Kirana}

Pada fase amatan 1 menuju intervensi terjadi penurunan rerata pikiran dan perilaku self injury, begitupun tren dari yang tadinya menanjak (-) kemudian menurun $(+)$. Sementara untuk standar deviasi terjadi peningkatan, baik pada pikiran maupun pada perilaku. Standar deviasi paling besar nilainya di fase intervensi. Hal ini berarti Kirana merasakan perubahan suasana hati yang besar di ketika ELT diberikan. Kirana merasakan kondisinya membaik sekaligus memburuk. Ada perasaan lega ketika mengenali para pemain dalam diri, namun juga tidak terima dengan pemain tersebut. Di sisi lain, ada perasaan merasa lebih hidup di realita, tidak merasakan kosong dan terasing, namun juga ada perasaan kehilangan bahwa ini bukan dirinya yang biasa. Sementara perubahan positif yang terlihat jelas adalah setelah Kirana merasakan sesi yang paling bermanfaat dan bermakna bagi dirinya yaitu sesi cinta dan syukur. Kirana menghayati dan menerima bahwa semua yang terjadi di dalam hidup, baik itu yang menyakitkan sekalipun adalah rencana Tuhan yang indah, sehingga ia merasakan perasaan- 


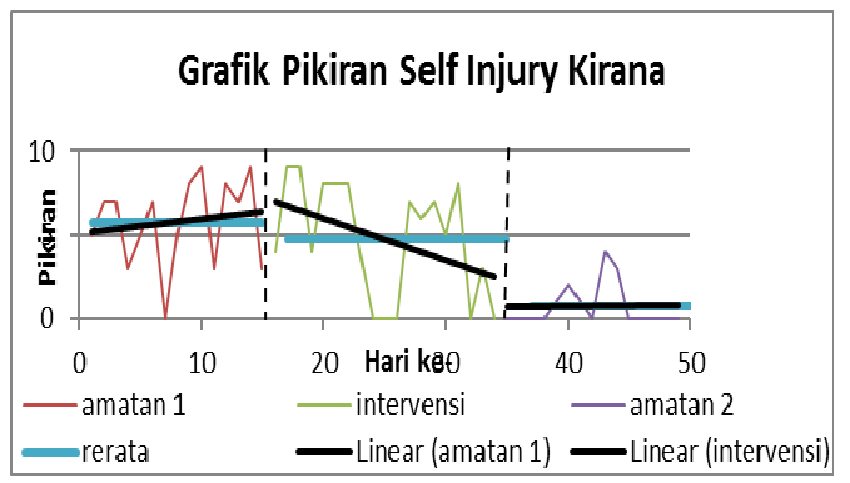

Gambar 1. Grafik Pikiran untuk Self Injury Kirana

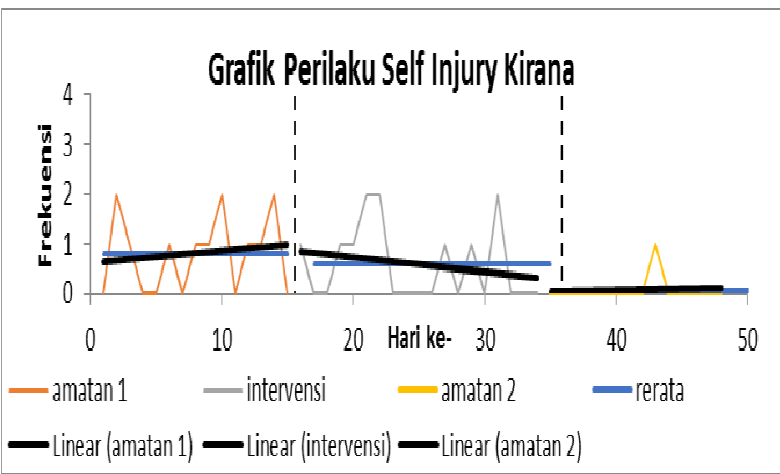

Gambar 2. Grafik Perilaku Self Injury Kirana

Tabel 2.

Uraian (rerata, standar deviasi, tren, dan perubahan level) pikiran untuk melakukan self injury pada Kirana

\begin{tabular}{llll}
\hline \multicolumn{1}{c}{ Keterangan } & \multicolumn{1}{c}{ Amatan 1 } & \multicolumn{1}{c}{ Intervensi } & \multicolumn{1}{c}{ Amatan 2 } \\
\hline Rerata & 5.733 & 4.736 & 0.733 \\
SD & 2.604 & 3.396 & 1.279 \\
Tren & Menanjak (-) & Menurun $(+)$ & Datar (stabil) \\
Perubahan Level & & $1(-)$ & $0(+)$ \\
\hline
\end{tabular}

Tabel 3.

Uraian (rerata, standar deviasi, tren, dan perubahan level) perilaku self injury pada Kirana

\begin{tabular}{llll}
\hline Keterangan & Amatan $\mathbf{1}$ & Intervensi & Amatan 2 \\
\hline Rerata & 0.8 & 0.578 & 0.067 \\
Standar Deviasi & 0.774 & 0.768 & 0.258 \\
Tren & Menanjak (-) & Menurun $(+)$ & Datar (stabil) \\
Perubahan Level & & $1(-)$ & $0(+)$ \\
\hline
\end{tabular}

perasaan positif terkait keberhargaan dan kebersyukuran.

Pada fase intervensi menuju amatan 2 terlihat perubahan positif yang cenderung stabil atau menetap baik pada pikiran maupun perilaku self injury. Yaitu terjadi penurunan rerata dan standar deviasi. Sementara untuk tren, cenderung menetap. Perubahan positif ini bermakna Kirana menemukan banyak sudut pandang baru yang bisa ia pelajari. Kirana bisa menerima dirinya apa adanya dan tidak menuntut diri, ia pun lebih optimis menjalani hari-hari, sekalipun sesekali pikiran untuk self injury muncul namun tidak separah ketika sebelum intervensi. Kirana mengatakan mulai dapat mengendalikannya dengan mencoba meminta pertolongan pada Tuhan.

\section{Partisipan Satrio}

Pada fase amatan 1 menuju intervensi terjadi penurunan rerata dan penurunan standar deviasi. Hal ini bermakna bahwa Satrio merasakan perubahan setelah mendapatkan perlakuan ELT. Titik balik perubahannya terjadi setelah mengenali para pemain dalam diri, pikiran dan perilaku negatif seperti mengejek, membodoh-bodohkan, menyalahkan, dan menyakiti diri menjadi sangat jarang muncul, kalaupun muncul mampu Satrio kendalikan. Selain itu, Satrio merasakan lebih menerima dan terbuka dengan segala yang terjadi dalam hidup, Satrio 


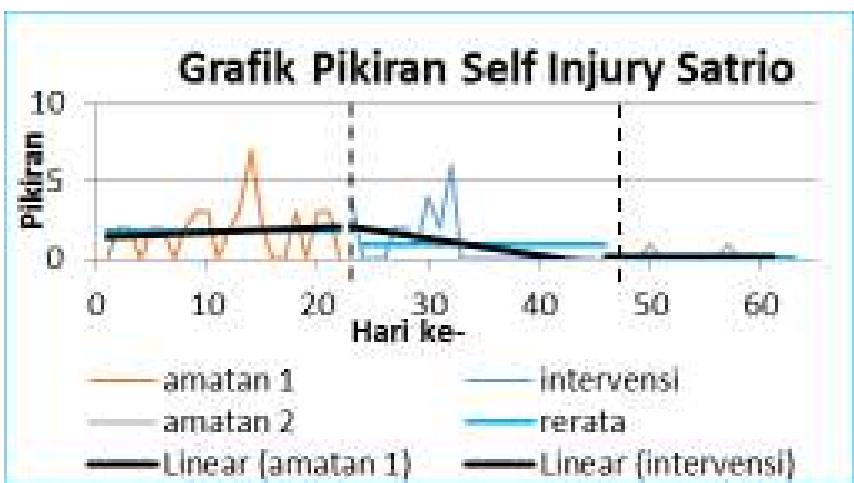

Gambar 4. Grafik Perilaku Self Injury Satrio

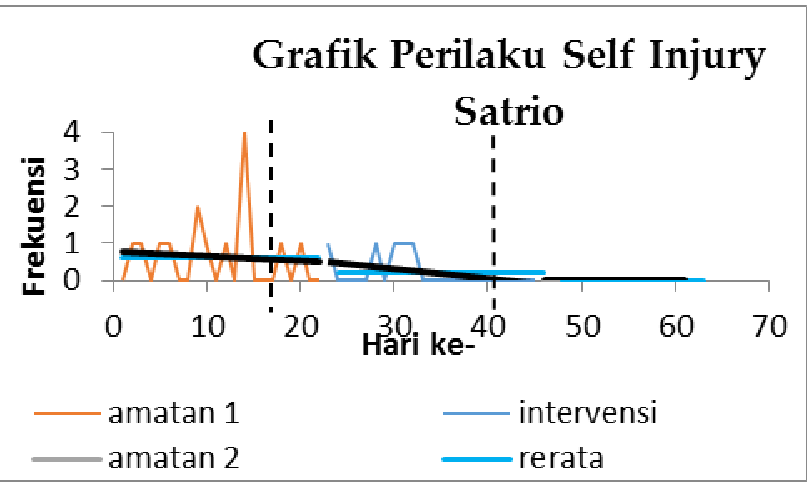

Gambar 4. Grafik Perilaku Self Injury Satrio

Tabel 4.

Uraian (rerata, standar deviasi, tren, perubahan level) pikiran untuk melakukan self injury pada Satrio

\begin{tabular}{llll}
\hline Keterangan & Amatan $\mathbf{1}$ & Intervensi & Amatan 2 \\
\hline Rerata & 1.772 & 0.913 & 0.125 \\
SD & 1.716 & 1.676 & 0.341 \\
Tren & Menanjak (-) & Menurun $(+)$ & Datar (stabil) \\
Perubahan Level & & $4(-)$ & $0 \quad(+)$ \\
\hline
\end{tabular}

Tabel 5 .

Uraian (rerata, standar deviasi, tren, perubahan level) perilaku self injury pada Satrio

\begin{tabular}{llll}
\hline Keterangan & Amatan 1 & Intervensi & Amatan 2 \\
\hline Rerata & 0.636 & 0.217 & 0 \\
SD & 0.953 & 0.421 & 0 \\
Tren & Menurun $(+)$ & Menurun $(+)$ & + \\
Perubahan Level & & $1(-)$ & $0(+)$ \\
\hline
\end{tabular}

lebih memiliki harapan dan mengerti tujuan hidup.

Pada fase intervensi menuju amatan 2 terlihat perubahan positif yang cenderung stabil atau menetap, baik pada pikiran maupun perilaku self injury. Yaitu penurunan rerata dan penurunan standar deviasi. Bahkan untuk perilaku menjadi 0 atau tidak ada sama sekali. Hal ini bermakna bahwa Satrio merasa lebih stabil, tidak seperti sebelumnya yang gampang sekali mengalami perubahan suasana hati. Kalaupun ada pikiran untuk menyalah-nyalahkan diri tidak separah sebelum intervensi dan hanya sebentar karena mampu Satrio kendalikan.

\section{Partisipan Laksmi}

Pada Laksmi terdapat perubahan postif yaitu penurunan pikiran dan perilaku self injury dari fase amatan 1 menuju intervensi. Penurunan rerata, penurunan standar deviasi. Hal ini bermakna terjadi penurunan pikiran dan perasaan negatif berupa cemas, overthinking, sering menyalahkan diri dan merasa merepotkan orang lain berkurang setelah ELT. Terlebih di sesi kehendak, Laksmi seperti mendapat pencerahan bahwa dirinya tidak seburuk seperti yang dipikirkan sebelumnya.

Pada fase intervensi menuju amatan 2, pikiran self injury pada Laksmi mengalami penurunan, sementara perilaku self injury pada Laksmi cenderung 


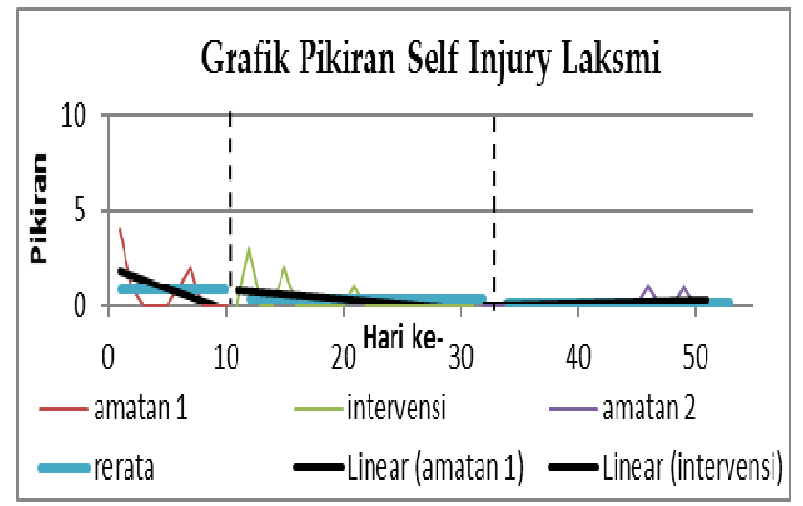

Gambar 5. Grafik Pikiran Self Injury Laksmi

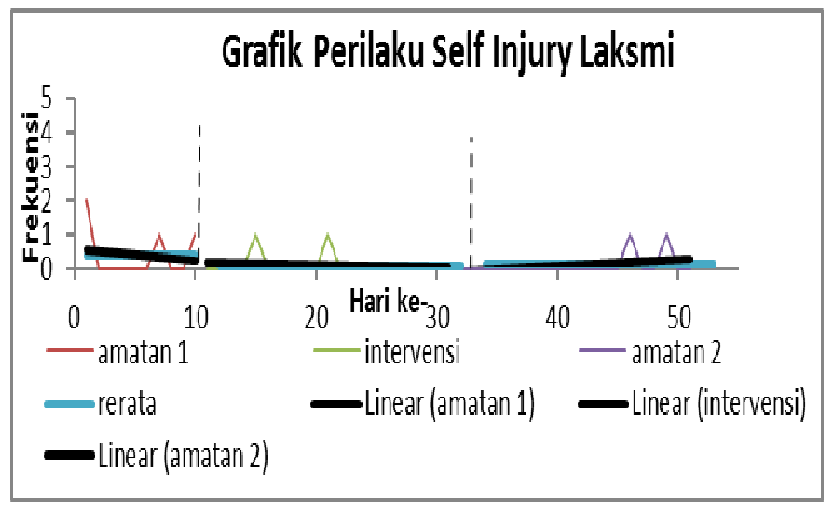

Gambar 6. Grafik Perilaku Self Injury Laksmi

Tabel 6.

Uraian (rerata, standar deviasi, tren, perubahan level) pikiran untuk melakukan self injury pada Laksmi

\begin{tabular}{llll}
\hline Keterangan & Amatan 1 & Intervensi & Amatan 2 \\
\hline Rerata & 0.8 & 0.285 & 0.1 \\
SD & 1.316 & 0.783 & 0.307 \\
Tren & Menurun $(+)$ & Menurun $(+)$ & Datar (stabil) \\
Perubahan Level & & $0(+)$ & $0(+)$ \\
\hline
\end{tabular}

Tabel 7.

Uraian (rerata, standar deviasi, tren, perubahan level) perilaku self injury pada Laksmi

\begin{tabular}{llll}
\hline Keterangan & Amatan 1 & Intervensi & Amatan 2 \\
Rerata & 0.4 & 0.095 & 0.1 \\
SD & 0.699 & 0.3 & 0.307 \\
Tren & Menurun $(+)$ & Mendatar $(+)$ & Menanjak $(-)$ \\
Perubahan Level & & $1(-)$ & $0 \quad(+)$ \\
\hline
\end{tabular}

meningkat. Rerata pikiran self injury turun sebesar 0.185, sementara perilaku self injury naik sebesar 0.005. Sedangkan pada standar deviasi, terjadi penurunan standar deviasi untuk pikiran self injury sebesar 0.476, sementara untuk perilaku naik sebesar 0.007. Terlihat bahwa untuk pikiran self injury pada Laksmi mengalami penurunan sementara untuk perilaku cenderung meningkat, sekalipun peningkatannya sangat kecil. Hal ini bermakna kondisi Laksmi cenderung stabil namun ketika menghadapi situasi yang menekan seperti UTS, Laksmi kembali merasakan kekhawatiran dan kegelisahan sehingga muncul pikiran dan perilaku self injury namun tidak separah sebelum mengikuti terapi.

\section{Diskusi}

Penelitian ini menemukan bahwa Empathic Love Therapy dapat menurunkan pikiran dan perilaku self injury. Sesuai dengan temuan penelitian sebelumnya bahwa ELT terbukti meningkatkan keberhargaan dan penerimaan diri (Saragih, 2014; Tittarini, 2014; Sagala, 2015; Widiasari, 2015; Yana, 2015). Rasa berharga dan penerimaan atas segala elemen dalam diri membuatnya menemukan diri yang sejati yang penuh potensi dan sejatinya tidak merusak diri.

Rangkaian proses dalam ELT membawa perubahan positif pada diri partisipan. Dimulai dari mengenali para pemain dalam diri, yaitu menyadari keseluruhan aspek dalam diri, tidak hanya menyadari pola kepribadian yang 
terbentuk atas segala pengalaman maupun luka di masa lalu, namun juga mampu bertindak sebagai pengamat yang melakukan introspeksi sehingga memunculkan pemahaman baru yang menyeluruh tentang kebutuhan diri. Mengenali elemen diri merupakan langkah awal menuju perubahan. Tahap berikutnya adalah peneriman, menerima semua elemen diri baik elemen yang menyenangkan ataupun yang menyakitkan dalam diri yang membuka gerbang menuju restrukturisasi terhadap pola ataupun keyakinan lama yang bersifat membatasi atau bahkan merusak diri, dalam penelitian ini yaitu pikiran dan perilaku self injury. Restrukturisasi tersebut menyadarkan partisipan akan kekuatan tersembunyi yang bersifat positif, bebas, spontan dan tidak terbatas. Kesadaran ini membuka jalan menuju keterhubungan dengan diri sejati yang penuh dengan kebijaksanaan, kebenaran dan kebaikan.

Temuan yang menarik dalam penelitian ini adalah terdapat kemiripan antar partisipan, yaitu self injury sebagai fungsi regulasi dan self punishment. Fungsi regulasi yaitu self injury digunakan untuk melepaskan diri dari pikiran, perasaan, ataupun emosi negatif yang menghantui (Klonsky, 2009; Nock, 2010). Sementara self punishment dikatakan sebagai ekspresi kemarahan, kebencian dan perasaan menyalahkan diri yang terus menerus sehingga merasa dirinya pantas untuk mendapat hukuman (Klonsky, 2009).

Temuan dalam penelitian ini juga sejalan dengan yang disebutkan (Nock, 2010) bahwa ekspresi emosi yang tinggi di keluarga merupakan salah satu faktor resiko yang memengaruhi kemunculan dan keparahan self injury. Anak yang dibesarkan dengan dengan ekspresi emosi emosi yang tinggi di keluarga akan mengembangkan gaya berpikir kritik berlebihan terhadap diri dengan jalan selfabuse dan self-punishment (Beatens et al., 2015; Glassman et al., 2007). Pada penelitian ini, Kirana mendapat kekerasan verbal oleh Bapak, sementara Satrio mendapat kekerasan verbal dan fisik oleh Ibu.

Selain itu temuan penelitian ini juga sejalan dengan penelitian (Glassman et al, 2007) yang mengungkapkan hubungan yang signifikan antara childhood maltreatment (berupa physical neglect, emotional abuse, dan sexual abuse) dengan munculnya perilaku self injury. Dikatakan bahwa emotional abuse (pengabaian emosi) dan sexual abuse (pelecehan seksual) memiliki hubungan yang paling kuat terhadap kemunculan self injury. Hal tersebut terlihat pada Kirana dan Satrio yang mendapatkan pengabaian emosi oleh orang terdekat, sementara Laksmi yang pernah mendapatkan pelecehan seksual oleh sepupunya.

Pengamatan kondisi para partisipan seperti pikiran-pikiran negatif, kemarahan, kebencian, perasaan tertekan, kosong, tidak adil, tidak aman paling besar ditemukan di pertemuan ke-2 dan ke-3 (khusus Satrio mulai dari pertemuan-1 s/d pertemuan-3). Pada pertemuan-pertemuan tersebut sesi yang dibahas adalah eksporasi aku dan eksplorasi luka. Sesi eksplorasi aku dan eksplorasi luka merupakan sesi yang paling berat karena para partisipan mulai menyadari polapola kepribadian yang terbentuk akibat luka ataupun pengalaman yang tidak menyenangkan di masa lalu (Firman \& Gila, 2002). Oleh karenanya dibutuhkan kekuatan dan cinta untuk melihat bagian tersebut dan menerimanya sebagaimana adanya (Firman \& Gila, 2010). Penerimaan rata-rata muncul di pertemuan ke-4 dan terus berkembang menjadi penerimaan yang lebih besar di pertemuan-pertemuan selanjutnya. Hal ini tampak dari kondisi 
partisipan yang semakin positif mulai dari pertemuan ke-4 dan terus meningkat sampai pertemuan-pertemuan selanjutnya yaitu pertemuan ke-5, ke-6, dan ke-7.

Berbagai faktor dapat berpengaruh terhadap hasil penelitian adalah maturity dan history. Maturity terjadi karena perubahan partisipan dapat terjadi karena perubahan alamiah. Untuk history, setiap partisipan mengalami peristiwa yang berbeda selama intervensi diberikan. Kejadian yang berlangsung pada saat yang bersamaan dengan intervensi dapat berdampak pada hasil pengukuran (Shadish, et al., 2002). Pada Kirana kondisi pikiran dan perilaku self injury yang naik turun disebabkan oleh history, yaitu sehari sebelum melakukan intervensi, pikiran dan perilaku self injury Kirana tiba-tiba berkurang karena ia baru saja mendapatkan dukungan dari pacarnya. Selain itu, pada intervensi dan amatan 2 terlihat kondisi pikiran dan perilaku self injury Kirana yang naik turun karena maturity. Diakui Kirana, butuh waktu 10 hari setelah intervensi sampai akhirnya ia bisa stabil dan mengendalikan diri. Pada Satrio, history misalnya deadline pengumpulan tugas yang semakin dekat, tugas yang semakin bertumpuk, kejadian ataupun peristiwa tak terduga yang menyebabkan naik turunnya pikiran dan perilaku self injury pada Satrio. Untuk maturity terlihat dari insight yang diperoleh Satrio setelah pertemuan ke-4 yaitu saat eksplorasi luka. Satrio menjadi lebih stabil untuk tidak berpikiran ataupun tidak melakukan self injury, bahkan untuk perilaku, sampai wawancara follow-up, terlihat bahwa Satrio sudah tidak lagi melakukan self injury. Pada Laksmi, history sangat jelas terlihat pada amatan 1, Laksmi mengetahui kenyataan pahit bahwa orang yang disukainya ternyata sengaja jauh darinya, hal ini membuat pikiran dan perilaku self injury Laksmi meningkat. Selain itu di amatan 2 saat mendekati UTS dan tugastugas yang semakin menumpuk merupakan kondisi yang menekan dan membuat pikiran dan perilaku self injury Laksmi semakin meningkat. Selain itu sikap Laksmi yang pemendam, belum terbuka sangat memengaruhi proses intervensi.

Kegiatan yang dilakukan dalam sesi intervensi memiliki kekuatan dan kelemahan yang perlu dievaluasi. Pada sesi eksporasi aku dan eksplorasi luka bisa merupakan bumerang tersendiri jika tidak dilakukan secara cermat karena kedua sesi ini merupakan sesi yang paling berat dan banyak menimbulkan ketergugahan perasaan negatif berupa kemarahan, kebencian, perasaan sedih, terasing, dan lain-lain. Sehingga sangat penting bagi fasilitator untuk membekali partisipan dengan teknik-teknik praktis untuk menjaga kestabilan emosinya. Salah satunya adalah relaksasi. Berdasarkan tabel relasasi, baik Kirana, Satrio maupun Laksmi merasa lebih santai dan tenang ketika mencoba melakukan relaksasi pernafasan di rumah. Smith (2007) menjelaskan bahwa relaksasi adalah metode yang digunakan untuk mengurangi ketegangan-ketegangan neurofisiologis.

\section{Kesimpulan}

Empathic Love therapy dapat menurunkan pikiran dan perilaku self injury. Rangkaian proses dalam ELT membawa perubahan yang positif dan menyumbang terhadap penurunan pikiran dan perilaku self injury.

ELT membawa pengaruh yang paling besar pada partisipan yang memiliki kemauan, kematangan, dan kesiapan yang tinggi dalam proses terapi. Penurunan pikiran dan perilaku self injury sangat terlihat, terlebih setelah sesi 
eksplorasi aku atau mengenali segala elemen dalam diri.

\section{Saran}

Penelitian selanjutnya perlu pengukuran kesiapan partisipan untuk membantu memperkirakan keterbukaan partisipan dalam terapi, sehingga fasilitator bisa mengantisipasi dengan melakukan building raport lebih lama. Perlu ada penelitian lebih lanjut untuk individu yang melakukan self injury sebagai fungsi interpersonal misalnya individu melakukan self injury karena mencari perhatian, ingin berkomunikasi dan ajang berkumpul dengan teman, ataupun karena alasan praktis yaitu self injury untuk dapat produktif lagi dalam bekerja.

Partisipan dapat menggunakan pengalaman positif yang didapatkan selama terapi di luar sesi terapi, misalnya menyadari penerimaan diri terhadap pengalaman yang menyakitkan, menyadari kualitas tersembunyi dalam sesuatu yang dirasa negatif, menyadari aspirasi sebagai penggerak untuk maju menggapai cita-cita, dan menghadirkan keterhubungan dengan Tuhan sebagai penolong yang utama. Partisipan disarankan untuk mengulang relaksasi pernafasan karena dapat memberikan perasaan rileks dan santai, serta mengurangi ketegangan yang dirasakan.

\section{Kepustakaan}

Albores-Gallo L, Méndez-Santos JL, Xóchitl-Garcia Luna A, DelgadilloGonzález Y, Chávez-Flores CI, Martínez OL. (2014). Nonsuicidal self-injury in a community sample of older children and adolescents of Mexico city. Actas Esp Psiquiatr. 42(4), 159-168.

Baetens, I., Claes, L., Hasking, P., Smits, D., Grietens, H., Onghena, P., \&
Martin, G. (2015). The relationship between parental expressed emotions and non-suicidal selfinjury: The mediating roles of selfcriticism and depression. Journal of Child Family Study, 24, 491-498.

Barlow, D. H., \& Hersen, M. (1987). Singlecase experimental designs: Strategies studying behavior change second edition. New York: Pergamon Press.

Bentley, K. H., Nock, M. K., Barlow, D. H . (2014). The four-function model of nonsuicidal self-injury: Key directions for future research. Clinical Psychological Science, 2(5), 638-656.

Firman, J., \& Gila, A. (2002). Psychosynthesis: A psychology of the spirit. Albany, NY: State University of New York Press.

Firman, J., \& Gila, A. (2010). A psychotherapy of love. Albany, New York: State University of New York Press.

Glassman, L. H., Weierich, M. R., Hooley, J. M., Deliberto, T. L., \& Nock, M. K. (2007). Child maltreatment, nonsuicidal self-injury, and the mediating role of self-criticism. Behaviour Research and Therapy, 45, 2483-2490.

Glenn, C. R., Klonsky, E. D. (2009). Social context during non-suicidal selfinjury indicates suicide risk. Personality and Individual Differences, 46(1), 25-29.

Glenn C. R, Klonsky E. D. (2013). Nonsuicidal self-injury disorder: An empirical investigation in adolescent psychiatric patients. Journal of Clinical Child Adolescent Psychology, 42, 496-507.

Gratz, K. L, Dixon-Gordon, K. L., Chapman, A. L., \& Tull, M. T. (2015). Diagnosis and characterization of DSM-5 nonsuicidal self-injury 
disorder using the clinicianadministered nonsuicidal self-injury disorder index. Assessment, 22(5), 527-539.

Guan, K., Fox, K. R., \& Prinstein, M. J. (2012). Nonsuicidal self-injury as a time-invariant predictor of adolescent suicide ideation and attempts in a diverse community sample. Journal of Consulting and Clinical Psychology, 80(5), 842-849.

Kazdin, A. E. (2011). Single-case research designs: Methods for clinical and applied settings second edition. New York: Oxford University Press.

Klonsky, E. D. (2007). The functions of deliberate self-injury: A review of the evidence. Clinical Psychology Review, 27, 226-239.

Klonsky, E. D. (2009). The functions of selfinjury in young adults who cut themselves: Clarifying the evidence for affect-regulation. Psychiatry Research, 166, 260-268.

Klonsky, E. D. (2011). Non-suicidal selfinjury in United States adults: prevalence, sociodemographics, topography and functions. Psychological Medicine, 41, 1981-1986.

Klonsky, E. D., Glenn, C. R. (2009). Assessing the functions of nonsuicidal self-injury: Psychometric properties of the inventory of Statements About Self-injury (ISAS). Journal of Psychopathology Behaviour Assessment, 31, 215-219.

Kool, N., Meijel, B. V., \& Bosman, M. (2009). Behavioral change in patients with severe self injurious behavior:

A patients's perspective. Journal of Psychiatric Nursing, 23(1), 25-31.

Laye-Gindhu, A., \& Schonert-Reichl., K. A. S. (2005). Nonsuicidal self-harm among community adolescents: Understanding the "whats and whys" of self-harm. Journal of Youth and Adolescence, 34, 447-457.

Lloyd-Richardson, E. E., Perrine, N., Dierker, L., \& Kelley, M. L. (2007). Characteristics and functions of nonsuicidal self-injury in a community sample of adolescents. Psychological Medicine, 37, 1183-1192.

Manca, M., Presaghi, F, \& Cerutti, R. (2014). Clinical specificity of acute versus chronic self-injury: Measurement and evaluation of repetitive non-suicidal selfinjury. Psychiatry Research, 215, 111119.

Muehlenkamp, J. J., Claes, L., Havertape L., \& Plener, P. L. (2012). International prevalence of adolescent nonsuicidal self-injury and deliberate self-harm. Child and Adolescent Psychiatry and Mental Health, 6(10), 1-9.

Marshall, Sheila K., Weaver, Lauree C. T., \& Stattin, Hakan. (2013). Nonsuicidal self-injury and depressive symptoms during middle adolescence: A longitudinal analysis. Journal of Youth Adolescence, 42, 12341242.

Nock, M. K., \& Prinstein, M. J. (2004). A functional approach to the assessment of self-mutilative behavior. Journal of Consulting and Clinical Psychology, 72, 885-890.

Nock, M. K., \& Prinstein, M. J. (2005). Clinical features and behavioral functions of adolescent selfmutilation. Journal of Abnormal Psychology, 114, 140-146.

Nock, M. K. (2010). Self-injury. Annual Review of Clinical Psychology, 6, 339363.

Pierro, R. D., Sarno, I., Perego, S., Gallucci, M., \& Madeddu, F. (2012). Adolescent nonsuicidal self-injury: The effects of personality traits, 
family relationships and maltreatment on the presence and severity of behaviours. European Child and Adolescent Psychiatry, 21, 511-520.

Ruefller. (1995). Para pemain di dalam diri kita (Terjemahan). Surabaya: Fakultas Psikologi Universitas Surabaya.

Sagala, A. (2015). Empathic love therapy untuk menurunkan depresi pada orang dengan HIVIAIDS. (Tesis tidak dipublikasikan). Fakultas Psikologi, Universitas Gadjah Mada, Yogyakarta.

Saragih, S. (2014). Emphathic love therapy pada perempuan depresi korban kekerasan dalam rumah tangga. (Tesis tidak dipublikasikan). Fakultas Psikologi, Universitas Gadjah Mada, Yogyakarta.

Shadish, W. R., Cook., T. D., \& Campbell, D. T. (2002). Experimental and designs for generalized causal inference. Boston: Houghton Mifflin Company.

Smith, J. C. (2007). The new psychology of relaxation and renewal. Special Issue, 35(3), 85-89.
Tittarini, D. G. (2014). Empathic love therapy pada mahasiswa yang mengalami kecemasan. (Tesis tidak dipublikasikan). Fakultas Psikologi, Universitas Gadjah Mada, Yogyakarta.

Widiasari, E. (2015). Empathic love therapy untuk menurunkan depresi. (Tesis tidak dipublikasikan). Fakultas Psikologi, Universitas Gadjah Mada, Yogyakarta.

Yana, I. P. A. (2015). Empathic love therapy untuk menurunkan kecemasan pada orang dengan gangguan gagap. (Tesis tidak dipublikasikan). Fakultas Psikologi, Universitas Gadjah Mada, Yogyakarta.

Yurkowski, K., Martin, J., Levesque, C., Bureau, C. F., Lafontaine, M. F., Cloutier, P. (2015). Emotion dysregulation mediates the influence of relationship difficulties on nonsuicidal self-injury behavior in young adults. Psychiatry Research, 228, 871-878. 